\title{
THE ZERO DECADE OF ARCHITECTURE IN BELGRADE AND SERBIA
}

\author{
A B S T R A C T
}

The intention of this paper is to contemplate the root problem that was prevalent in the architecture in Serbia and in Belgrade in the last decade, and to try to provide some insight into few issues and discuss the future solutions: what are the core values and what is specific in the recent architecture of Belgrade/ Serbia, what was lacking in the theoretical and practical areas of architecture and what is the significance of the realized architecture at the local, regional or the European level. The challenge of keeping the traditional architecture, yet incorporate proven global concepts that are both aesthetically pleasing, yet serve a practical purpose, was in conclusion presented as the emulation of the new ideas on old notions, integration of global concepts, local knowledge and experience to deliver superior quality architectural achievements, based on highly motivated, professional, visionary, resourceful, experienced or promising Serbian architects. 
The architecture in Belgrade and Serbia, its creative potential and implemented concepts in the recent period, are barely known today, even at the regional level. The reason for that certainly being closing of the culturological and communicational theoretical and practical interaction with the international community and the overall isolation during the nineties, which continued over the past decade too, with austere and incomplete flow or exchange of information, very few exhibitions of the achievements of the Serbian architecture in the region or in Europe, with acutely small number of published works, texts, books and reviews of works, either locally or within Europe. What has actually happened in the Serbian architecture and, first of all, in Belgrade being the major stage of architectural trade? What significance does Serbian architecture have through the implemented concepts and projects at the regional or at the European level? The lack of quality and professional architectural publications with a critical approach, and the literature on architecture at large, the insufficient interest shown by the professional public as well as the public in general, and also the weak will of the government and its competent authorities to present the „new era“of the last decade through architecture, leave behind a void in a very important discipline - the art and skill of building construction. This unfavorable situation is not encountered in Europe, or in the regions where architecture is accompanied by a corresponding logistics in the form of the exhibitions, books, publications, reviews, forums, debates, professional organizations, the funds invested and discussions held in all directions.

Architecture expresses the time and the context of its genesis, it indirectly or more directly speaks of not only the tactics in relations amongst the architect, the client or the investor, the legitimacy of state and municipal administration's intentions, but also projects the intentions and quality in the culture, the environment and politics. However, despite the incessant, powerful and omnipresent building construction taking place in Belgrade, one of the reasons for the monologue and dialogue emptiness on the course of progress in the creative field of Serbian architecture, if any at all, perhaps rests with the few artifacts of auteur, standard and high-quality architecture. It is certain that its metropolitan pulse is not sufficiently supported and provided with the necessary incentive by the open, democratic, market orientated processes through organization of a larger number of domestic and international public competitions in the field of architecture to at least promote the intrinsic and badly needed urban services. This may have been attributed to the inaccessibility or absence of the government and municipal public tenders for a greater number of quality architectural bureaus and the insufficient involvement of the renowned creative architects / planners and / or the new generations of architects. 
The question in view of the prerequisites for the high quality standards in architecture that and innovative concepts be translated into superior could through ingenious architectural achievements of highest values is imposed at this point. Would the unregulated status of the architects in Serbia be also the cause of this phenomenon, in a contemporary, Europe orientated architecture in Serbia?

\section{THE BELGRADE CONTEXT - THE KEY NOTES}

The City of Belgrade has always held a special position in the rather young Serbian architecture (not even two centuries old), as a dynamic metropolis, which, although it lost its role of the federal Capital not so long ago, has not renounced its open, self-confident metropolitan and cosmopolitan spirit in the new, narrowed state space of the Republic of Serbia. Belgrade, the Capital of the former Kingdom of the Serbs, the Croats and the Slovenes, then the Capital of the Federal National Republic of Yugoslavia and finally the Capital of the Socialist Federal Republic of Yugoslavia until 1991, and since $2006^{1}$ the Capital (having 1.5 million inhabitants and incorporating 17 urban municipalities), of the independent Republic of Serbia, with the population of 7.5 million inhabitants. Belgrade, situated at the confluence of two rivers, the Sava and the Danube, has an extraordinary geostrategic and geographical position, widely spreading in all directions sits amongst the verdant environment of its riverbanks, but with the seven bridges that prove to be insufficient to service the ever pulsing city and still without the independent system of transportation - the underground or light rail traffic. Despite the fact that several new, smaller city hotels have been built, it is paradoxical to its morphological and functions-wise metropolitan character, that Belgrade hotels can accommodate only about 3,000 guests.

In a brief overview of the Belgrade context, in several places, the comparative conclusions and quotations from Belgrade the Capital, a publication edited by Vladimir A. Milić and Vladan Djokić (2006) in a form of almost a dialogue, will be used. The author of one of the texts from the mentioned publication, Vladimir A. Milić, in the text „Belgrade the Capital - Context” points out to the fact that: „Today, Belgrade has the political and administrative function of the Capital of the Republic of Serbia. Serbia is still a centralized country, where one quarter of its population lives in Belgrade or in its close vicinity. The most important and the biggest political, educational, industrial, communicative, media and infrastructural resources of Serbia are concentrated in this Serbianmetropolis. Belgrade the Capital is not perceived as the Capital of 
Serbia, but as the Capital of the Balkans or some other kind of the European area. In the prospects of the twenty-first century it could be a different Capital". ${ }^{2}$

The morphological dimension of a metropolitan city is also made of the recognizable buildings of many institutions from the past periods, although none of the buildings are more than two centuries old, the Belgrade fortress not taken into consideration. Namely, Belgrade has completely been destroyed for forty-four times. ${ }^{3}$ The incredible history of Belgrade at the frontier - the limes, and on the Military Road - Via militaris, and the countless alternations of wars and calamities, cataclysms and succession of diverse tribes and cultures throughout its nine-millennia-long history, as if visible through the fresh morphological layer of the past few periods, regardless of the lack of significant material traces of countless historical strata. ${ }^{4}$ Then no wonder it was precisely here that the highest hyperinflation in the history of mankind took place (1993), but life did not stop then and there. It is the open character and cosmopolitan heritage despite the discontinuity of cultures and mentalities that perhaps can be attributed to the city's ontological character in a miraculous way.

Today, Belgrade integrates two historical cities, the old town of Belgrade on the right bank of the Sava and Zemun on the right bank of the Danube, then the newly emerged town of New Belgrade (1947) between the left bank of the Sava and the right bank of the Danube, and several suburban settlements such as Lazarevac, Mladenovac, Obrenovac, Barajevo, Sopot, Surčin and others. The intensive construction of Belgrade which commenced upon its liberation from Turks and its reestablishment as the Capital in 1867, accompanied by the change of the Turkish oriental pattern following the example of the European leading cities, continued in the first years of the twentieth century, as well as in the period between the two World Wars in the contemporary European civilian society of the Kingdom of Yugoslavia, the construction laws of which, inter alia, required the facades and entrances overlooking the street to be "nice looking“. At the time even the smaller Serbian towns were examples of respectable, well-mannered citizenry, decorated with typical neoclassical schools, such as the Third (formerly the Eighth) Belgrade Grammar School. The majority of the constructed buildings date back to the „heroic" socialist period, from the building construction of New Belgrade, Karaburma, the section of King Alexander Street, to the areas of Voždovac, Banovo Brdo and Banjica, which, together with a few more settlements with illegal construction without any planned regulation, make today's sprawled, irregular, incoherent morphology of the city. The steady and uncontrolled inflow of population and permanent emergence of the new settlements have made the surrounding 
greenery disappear, as well as making the potentials of good city locations unattractive. There is also a consistent lack of concepts for the city development present, the trend of unconscientious and investor orientated urbanism, a continuous shortage of the infrastructure and the decay of the existing one. The past two decades could be characterized mainly by villas and residential blocks construction, and the last decade, also produced an abundance of the business buildings, shopping malls in the narrower city core and a few Orthodox temples.

The authors, Vedran Mimica, Petar Zaklanović, Ana Džokić and Milica Topalović, in the analytical and critical text „Belgrade the Capital“ from the eponymous publication, note: „In the physical sense, Belgrade is the city that experienced the growth of the urban structure through crisis in the past twenty years, from expressive centrality to polycentralization, fragmentation and horizontal expansion. At the same time, within the economic, political, cultural and educational domain it has experienced the implosion, loss of continuity, decrease and erasure of whole set of functions and links that where the driving force of the city development in the recent past. In contradiction between the physical transformation and the responding development at the economic, cultural and political level that has not ensued, the perception of general ruralization and retrograde tendencies has stabilized". 5

Nevertheless, construction has never ceased in Belgrade, not even during the imposed embargo and isolation from 1992 to 2001, not even during the threemonth' air strikes in 1999, only the volume and scope, functions and character of construction has changed. In the text "Belgrade the Capital - Context", Vladimir A. Milić further notices: „It was politically tolerated and was unofficially a socio-political maintaining the existential minimum in difficult civil war conditions, NATO aggression and rigid internal politics. Spatially, grey market economy generated itself through illegal construction. In the past fifteen years more that 200.000 buildings were erected at the outskirts as well as in the central area of Belgrade. Those buildings were solid but with poor infrastructure and shaped with no aesthetic or any other kind of building code of regulation. It might be concluded that grey market economy and illegal construction were and still are a parallel context within which Belgrade, as one can perceive it today, was shaped. Real consequences of this development have not been assessed". ${ }^{6}$

The paradox of parallelism and alteration of continuous aspiration to European modernism and pseudo-folklore characteristics of the suburban mentality, 
turbo-folk included, of opposite and sharply juxtaposed force of the ersonaland the general, public interest, can be perceived everywhere as accompanying characteristics of Belgrade fragmented ambiences. New Belgrade, the planned town of Contested modernism ${ }^{7}$, the former administrative centre of the Socialist Federal Republic of Yugoslavia, for decades has suffered the attacks upon its modern grid by inadequate and inappropriate buildings of varying sizes and uses. Parallel to this, in other city zones there emerged the family buildings of elite character, the villas, residences, business and residential blocks together with the illegal construction of solid edifices, this time construction-wise, that gradually encircled the city with external rings.

During the period of the social regime disintegration, the state apparatus made it possible to privatize socially owned apartments through by-outs. That brought about the illegal Wild Architecture ${ }^{8}$ in early nineties, which exploded with building upon the existing buildings with numberless castles in a limbo, and also building of such illegal, uncultivated, non-aesthetical architecture on free parcels. The open shopping malls made of market stands in the open air have made the siege of all important public spaces of the city, such as the Slavija Square and stranded several kilometers of King Alexander's Boulevard, the former Revolution Boulevard.

Further on, in the last period all city zones have become denser, from the oldest to the newest ones, with the increasing presence of the new investors and builders of suspicious reputation and engaged in the non-solid, thermally cold construction "undertakings“. Belgrade was not prepared to meet the untamed force knocking at its door and to shape it with a ready-made plan and infrastructure, and the mentioned force was always able, as an entropy force, to be ahead of it, as a faster and more powerful force. „Further fragmentary urban changes are encouraged by the context of transition: multiple impracticality of institutions, administrative and legislative structures and the resultant "investors urbanism" that usually acts as a parasite to the existing infrastructure, and avoids the delicate question of public interest". 9 All that complemented and enkindled the development of new surge of the international and domestic crisis and the new recession during the past years, which actually tells us that the trend of disintegration, which originated in the nineties, with arrogance of autocracy, corruption, hypocrisy, egoism, incompetence and bad manners, is still inevitably advancing just like a TT syndrome, tycoonization of transition. Sin-city, transgression city. ${ }^{10}$ 
The author of „Belgrade the Capital - Context“, Vladimir A. Milić, completesthe intricate picture of Belgrade: „It implies specific characteristics as Belgrade changed its basic role more that five times during the last century; the city 'in between', collage city, urban morphology made of hybrid patterns. Belgrade is a city that never sleeps, the city of dynamic pace of life, never boring or dull. Belgrade's Genius Loci attracts diverse people, ideas and ideologies, political concepts and small existential strategies". ${ }^{11}$

The new layer of architectural creation takes place within a context as sketched up to these lines. The complexity and contradiction of Belgrade context is an inevitable, irreplaceable factor and its influence upon the architects, the investors and clients, the citizens, the visitors and the foreigners is tantamount heterogeneous, paradoxical, unexpected, without any rules or patterns. Belgrade has been built by the masters of eclectic periods in architecture, confronted neoclassicists and romanticists, protagonists of the Serbian Byzantine style, the masters of secession, and between the two World Wars also by very successful anonymous builders, constructors, masons, and, exceptionally, the Belgrade's Modernists. ${ }^{12}$ The practice of mandatory public calls where architects from all over Yugoslavia could partake has brought about today's very interesting artifacts of European architecture heritage after the WWII.

Through research, in myriad of versatile construction undertakings, certain city positions have been marked as having the potential of correct and quality architecture since 2000, in the following city zones: continual section of residential buildings for elite family housing and residential blocks of exclusive housing on the trajectory Senjak-Dedinje-Banjica-Mačkov kamenLisičiji potok. Individual dispersive positions are in the zone of central city core of the old town and New Belgrade, as well as Banovo Brdo.

What were the criteria for selection of the proposed new paradigms? Primarily, the difference in the concept vis-à-vis the previous period models and realized changes of the contemporary approach to designing oriented towards the regional and immediate context of careful, unassuming architecture with a measure, new freshness, aesthetically acceptable and with its special genuine and experienced themes. The research of properties and characteristics of architecture are based on perceiving the kind of typology and the nature of investment, and also perceiving whether the buildings were the result of the direct order or architectural contest, public state tender, etc. Nearly all the mentioned buildings and architects have been awarded at certain architectural events in Belgrade or in Serbia, but not all the awarded works are here. The 
impersonal architecture of corporations and anemic architecture of imitation with snobbish themes and without original vigor, concept and context cannot be found in this text either.

The concepts in the architectural projects in Serbia undergo harsh devastation by ad hoc changes created by the investors themselves during works contractual process, without the architects' consent, or by contractors themselves, so certain buildings definitely remain without the segments of architecture, they remain standing as plain awkward constructions, like abandoned parentless children. The only defense for the futility of wasted years of work is the authors' renunciation of their authorship of the buildings constructed. Such cases are frequent, and examples of such relations can be seen in the Macura Museum building in Novi Banovci (Kucina, Katić) and in the University settlement of Block 32, New Belgrade (B. Mitrović).

THE “ZERO” YEAR, THE BELGRADE ARCHITECTURE SINCE 2000

Detection of new paradigms of change is found in the identified spirit of deposited stratum of new authentic research activities, whether they be completed works, concepts, designs, competition works, books or reviews, as a pretext of architecture. The protagonists engage in a constant search for the free and the new, with a need for a different purposefulness of meaning, in the context, frequently creating context. The topics are urban villas, new residential models, office buildings, sacral and memorial projects, reconstructions of cultural facilities, commercial facilities, interior design, competition designs, installations, international workshops, texts, in a new dynamic aesthetics, communication in a culture of richness in dialogue.

Primarily, in the continuity with the previous period, the public buildings that have undergone larger and more thorough reconstruction are conspicuous. The modernity and placidity of expression, stability of the innovative freshness of architectural concept of the reconstruction of JDP Theatre (Radojičić, Miljković, 2003, contest), symbolic key points of changes, and the refined minimalism of the reconstruction of the Belgrade Philharmonic (Vojvodić, Milojević, 2004) transcend the reality of the times in which they were executed. The Faculty of Political Sciences (Timotijević 2007- ) is in its second, new phase of reconstruction and building up on a very successful contemporary architectural passé-partouts and cuts. The reconstruction of the villa in Tolstojeva street (Milunović, 2008) shows a supreme tactile sophistication in selection of materials, positions and approach to reconstruction of special picturesque quality. 
New commercial facilities represent authentic artifacts of creative thinking in the design of new and special aesthetics, with activation and dynamic harmony of the context: a corporate building in Resavska Street and Porche administrative building (Vojvodić, 2009; 2008), Pristan, Port of Belgrade Terminal andMILŠPED Center, Stara Pazova (Vuja, Đurić, 2005, contest; 2007), HVB Bank, Rajićeva Street (B. Mitrović, 2003, contest), MPC, New Belgrade (Milunović, 2002). New standards of correct architecture have been implemented on the buildings of Holiday Inn hotel and Expo Centre in New Belgrade (V. Lojanica, 2007), as well as in the work of AGM group on the themes of Serbia's Laboratories administrative building and the sports facility in Zrenjanin (AGM and Kostić, 2007; AGM - Djulinac, Petrović, Rašković, Tomić, Jelić, 2009).

A special quality of the new completed projects of contemporary design are the social housing apartment buildings in New Belgrade (Šišović, Milanović, 2009, contest), in the Forum residential block in King Alexander's Boulevard (Mirković, Miletić, Vujović, 2008), Omladinska and Sarajevska streets in Belgrade (Vojvodić, Šišović, 2006; Vojvodić, 2007), in Stojana Protića street, (Krunić, 2006), in Milana Tepića and Lazarevačka streets (J. Mitrović, Miljković, 2004; 2006), in Dalmatinska street, in Đušina street, all Belgrade, (Miletić, 2002; 2004, contest), in the residential block in Makenzijeva Street (B. Popović, 2006), the residential block in Požeška Street in Banovo Brdo district (Sarić, 2004), in Kumanovska street, Belgrade (B. Mitrović, 2001). The completely new themes in Belgrade's architecture are condominiums, Lisičiji Potok (Musić, 2006, 2008).

A modern creative experiment deviating from modernism is an attribute of the villas and family houses in Augusta Cesarca Street (B. Mitrović, Milinković, 2009), the villa in Vukice Mitrović St. (B. Mitrović, 2009), the villas in Baje Pivljanina street (Radojičić, 2009; 2006) in Lisičiji Potok, in the district of Dedinje (Milunović, Ivanović-Vojvodić, 2004; 2006), the villa Augusta Cesarca street (Mirković, 2004), in Nake Spasić street 1st and 2nd phase (B. Mitrović, Šibalić, 2003; B. Mitrović, 2008), in Čolak Antina street (Musić, 2000), in Mačkov kamen (AGM, 2006; Bratuša, 2006; Sarić, 2004). In the consistency of the persistent, authentic experiment and creation of a special handwriting in the vocation of Zenitizam and Moderna, and their movement, with the idea of the new in the old, and vice versa, in the optics of the future, forms the professional trajectory of the architect Mustafa Musić, all the way from the Manifesto of $M E \check{C}$. 
On a larger scale of Serbia's new architecture new dynamic codes are noticed on the corporate building of Tekstil, Užice (Vesnić, Milenković, 2007) upgrading the existing context onto a new energy and visual level. The Memorial Centre in the Ravna Gora Mt. (Krunić, 2000) achieves supreme aesthetic value through the possibilities of rationalizing the already minimal given values, with a perfection of harmony of limitations imposed mutually by architecture and nature. Into the Temple of the Madonna in Knjaževac (B. Mitrović 2006) and the design of the Chapel in Kraljevo (Krunić, 2007) the fates of the multiple cultural heritage and authenticity were woven quietly and almost unperceivable, creating with new elements a new freshness of the regional and the religious which are characteristic of the new Lodgings of the Banjska Monastery (AGM, 2003), after the model of the excellent transposition of regional traditional values of the Monastic House in Uvac (Pešić, 1998). On KDC's residential and corporate buildings in Kraljevo (Vujović, 2008), a compelling architectural expression was realized in the modernist postulates, as well as intricate contextuality on residential blocks of Megdan in Užice (Timotijević, Balubdžić, 2004; 2006). The pedestrian street with central town square in Zrenjanin (B. Mitrović, 2006) is complementary to the realized public urban spaces of the European towns, with embedded regional characteristics and transposed tradition of the town through applied materials.

Calling for architectural contests with local communities and bringing up the topic of social housing in Serbia, UN Habitat made the first significant progress. The social housing residential blocks in Valjevo (Abadić, Milovanović, 2007, competition) possess an incontestable aesthetics and exceptionality in one of the most difficult and also utterly new themes in Serbian architecture.

In the themes of interior and public buildings design, such as shops, boutiques and cafes, Belgrade architects have achieved the remarkable and contemporary results presenting the spaces in the elegant atmosphere of light, materials and shapes made by minimal dashes. In this paper, the authors of several various generations have been mentioned, among whom being: Dušan Tešić, Branislav Mitrović, Vasilije Milunović, Mustafa Musić, Miodrag Mirković, Goran Vojvodić, Zoran Radojičić, Dejan Miljković, Jelena Ivanović-Vojvodić, Maja Vidaković, Grozdana Šišović, Daniela Stanković, Milena Kordić, Djordje Stojanović, Nataša Ilinčić, Jugoslava Kljakić.

The new informal groups and architectural studios (Medium International Development, Archtic, proASPECT, Biro.VIA, Zenit-inženjering,DVA STUDIO, 
AGM, ATD, NEO_architects, re:act studio, rel/al, Re:miks, Mikser, Oddo, Studio+Two, BRID-arcvs and others) replaced the bygone ones and easily achieved creative and universal parameters through a local context. Nevertheless, every successful work from Serbia is reminiscent of an exceptional and heroic achievement in every sense of the word because the current prerequi sites for successful architecture are very complex and still underdeveloped in Serbia.

The Symptoms of change (the new beginning, the year zero) lie in continuity and commitment to quality (ongoing works), creative capacity and potential in creating values, honesty and individual ethics in the architectural activity of a certain segment of the professional architectural elite of proven capacity for design with the freshness of the new age, whose outlines are becoming more and more distinct. It is above all a personal act, and not a consequence of a systemic approach of well-developed standards and mechanisms of society, but is in mutual collusion and close lateral ties of several generations. Their characteristics lie in heroics, in breaking the rule. The chronological boundary of the new is difficult to define, conditionally it is 2005, detected and announced, de facto earlier...

Several mixed and conditional generations, linked on the professional scene, in a continuum, making a firm structure, recognized in the works of Spasoje Krunić (1939) and Josip Pilasanović (1941), in the generation of Branislav Mitrović, Vasilije Milunović, Dušan Tešić (1948), Mustafa Musić, Mihailo Timotijević (1949), and Miodrag Mirković (1950) belong to creative persistence in accepting the modern and creating new values. Security in the same characteristics belongs to a mature generation which through a personal and authentic note brought about a new freshness on the postulates of the traditional and the regional, and Jovan Mitrović (1953), Blagota Pešić (1955), Borislav Petrović (1957), Goran Vojvodić (1959) and Sanjin Grbić (1963) belong to it.

Paradigmatic changes happened with the coming of age of a generation, maturing creatively from the first steps by their talent and intelligence, intuition and knowledge, creativity and sensibility, discipline and determination, primarily by their work through chaotic social parameters: the blockade, isolation, hyper-inflation, the air strikes... This group includes Dejan Miljković, Zoran Radojičić, Milan Đurić and Dejan Miletić (1967), Milorad Mladenović (1966), Aleksandru Vuja, Vladan Đokić (1963), Vladimir Lojanica, Vladimir Milenković (1969), Maja Vidaković (1972). Although very different 
in physiognomy and creative vocation, above all morally strong and pure, they are deeply woven into the base of Serbian architectural heritage understood in a cosmopolitan sense. The emerging generation, the young architects have been announced in the works of the high level results in the social housing domain by Zoran Abadić (1969), Grozdana Šišović (1976), Dejan Milanović (1973) and others.

Vladimir Mako in the preface to the catalogue of Serbia's participation at the Tenth Venice Biennial (2006) poses the question of the direct link between the non-adjacent time periods and the creators in Serbian architecture: „Irrespective of the cultural context of its appearance, the dynamism of aesthetic communication represents a true proof of a lively activity of the architectural effect, based on the creative consciousness of the role of the past, and the multi-layered vision of what is about to come. Initiated at the time of the search for positive architectural concepts of the new European nations of the nineteenth century, Serbian architecture still possesses the visionary power, which creatively integrates the moment of the contemporary with the associative perception of the past. This offers the possibility of continual development to the field of aesthetic interpretation of the creative process, the value of work, its cultural context and the dynamics of its perception". ${ }^{13}$

Symptoms of change were signaled suddenly and boldly in the exhibition titled The Serbia Dossier by Branko Pavić and Dejan Miljković in the Academy of Art in Berlin (2000) and in Vienna (2001), as the first breakthrough of a new idea and a new time, the same authors' participation at the 8th Biennale in Venice (2002), Deconstruction-Construction (1991-2002), naturally in the position of the critical reaction to the preceding decade of pain and emptiness. That same year Ana Marija Vujić-Kovenc's book 50 Serbian Architects highlights the protagonists of contemporary Serbian architecture, followed by Ljiljana Miletić Abramović's Belgrade Residential and Villa Architecture 1830-2002. A fragmentary critical look at Serbian architecture, Miloš Perović's Serbian Architecture of the Twentieth Century (2003), for the first time systematically and chronologically rounds off the national architectural space, pointing to the authentic importance of the avant-garde Zenitizam, GAMP, the Srpska Moderna group of Modernists, world-class Socialism Aesthetic designs, for the first time featuring a selection of modern Serbian architecture from the substratum of the artifacts of the 1990s.

That same year Ljiljana Blagojević's Modernism in Serbia: The Elusive Margins of Belgrade Architecture 1919-41 was published by the prestigious 
MIT. Others which followed were Vladan Đokić's Urban Morphology, the City and City Squares, Tanja Damljanović's Czech-Serbian Architectural Links 1918-1941 (2004), Vladimir Milenković's Architectural Form and Multi - Function (2004), Vladimir Mako's Aesthetics-Architecture (2005), Vladimir Milić's Urbanistički aspekti socijalnog stanovanja, Aleksandar Keković and Zorana Čemerikić's Moderna Niša 1920-1941, Mirjana Roter Blagojević's Residential Architecture in Belgrade in the 19th and Early 20th Centuries, Total Landscape, Mikica Mitrašinović's Theme Parks, Public Space (2006), Aleksandar Ignjatović's Yugoslavism in Architecture 19041941 (2007). The Zenith monograph 1921-1926 by Vidosav Golubović and Irina Subotić (2008), New Belgrade: the Challenged Modernism by Ljiljana Blagojević (2007), Vladan Djokić's Urban Typology: City Square in Serbia, The Garden City in Belgrade by Dragana Ćorović, Aesthetics-Architecture, volume 2, by Vladimir Mako (2009), and others.

New architectural essays by active architectural creators Vasilije Milunović, Mihailo Timotijević, Miodrag Mirković, Vladimir Milenković, Milan Maksimović, Dejan Miljković, the multi-media monograph The Architect Mustafa Musić, Zoran Manević's The Works of Stojan Maksimović (2006) and numerous others round off the new part of the national literary space. The voluminous research and comprehensive activity, a multi-media presentation through study and the exhibition placed Serbia's architectural activities in the focus through discontinued, transitional periods of circumstances determined by time, political systems, ideologies and states, and can be found in the study of Parallels and Contrasts - Serbian Architecture 1980-2005 (2007) by Ljiljana Miletić-Abramović, the custodian of Belgrade's Architecture Salon.

\section{THE RESULTS OF THE STRUGGLE AGAINST THE BACKDROP OF TIME, BOTH REGIONAL AND GLOBAL}

The opening of Serbia's architectural and construction landscape to Europe and the rest of the world, being necessary and inevitable in the creation of a new quality of modern architecture in Serbia and without which it is not possible to assess the extent of its achievement, was realized with the solo exhibitions of Spasoje Krunić (2004), Petar Arsić (2005), Branislav Mitrović (2006), Borislav Petrović and colleagues from AGM (2007) in Warsaw, Spasoje Krunić in Moscow (2007), Serbian Architecture of the 20th Century at the SCG Cultural Centre in Paris, New Endeavors at the Serbian pavilion at the 10th Biennal of Architecture in Venice, an organized participation of fifteen Serbian architects at the Tenth Salon of Architecture in Prague (2006), and 
participation of a large number of student exhibitors at the Prague Quadrennial of Theatrical Design.

Branislav Mitrović presented his works at the Days of Architecture in Piran, exhibiting the most valuable designs of Serbian architecture in the last decade (2007). The first multi-decade occasion of regional dialogue and comparison took place at the exhibition Architecture in Slovenia, Croatia and Serbia at the Beginning of the Twenty-First Century, at the international architecture week in Belgrade (2008). At the Urban Visions exhibition, at the Visions festival in Florence, Vladimir Milenković, Tatjana Stratimirović and Žaklina Gligorijević (2009) had a marked presentation and exhibition Belgrade 2020, presenting projects and visions of Belgrade's architects together with another dozen of world's most important cities.

Publication of the works of Serbian architects in foreign countries is an important precedent of the recognition of Serbian architecture. Snežana Vesnić's and Vladimir Milenković's 'Tekstil' building in Užice and Mustafa Musić's Museum of Modern Art in Novi Sad competition design, the Milšped Administrative Building by Milan Djurić and Aleksandru Vuja, the residential block by Jovan Mitrović and Dejan Miljković in Dedinje, the residential block by Jovan and Ružica Sarić in Banovo Brdo, the villa by Maša and Lav Bratuša in Mačkov kamen, the interview of Ivan Kucina, and other buildings presented were published in Hans Ibelings' A10 Architectural Review in Amsterdam (2007), Ivan Kucina's Design of House on the Mt. Avala was published in the London Blue Print (2005), Pristan (the pier) by Milan Djurić and Aleksandar Vuja in Oris (2008), Spasoje Krunić's Memorial centre on the Mt. Ravna Gora was published in Feydon's Atlas of the Contemporary World of Architecture (2004 and 2007).

\section{THE CHANCES OF A DIALOGUE AND INCENTIVE FACTORS}

That which is not also visible, not even in traces, is the demonstrative avantgarde paradigmatic action of Kengo Kuma, from which one should learn and get the knowledge. The creative avant-gardism of Japanese architect Kengo Kuma, the guest of the 2006 Salon of Architecture, set out in his lecture at the time, is an example of an imaginative architecture of reinterpreting and injecting traditional values into modern topics through continuous, patient and dedicated exploration and redefinition of concepts, elements and the atmosphere of the traditional and modern architecture, the philosophy, the anthropological aspect, the nature and location, the landscape and materials, 

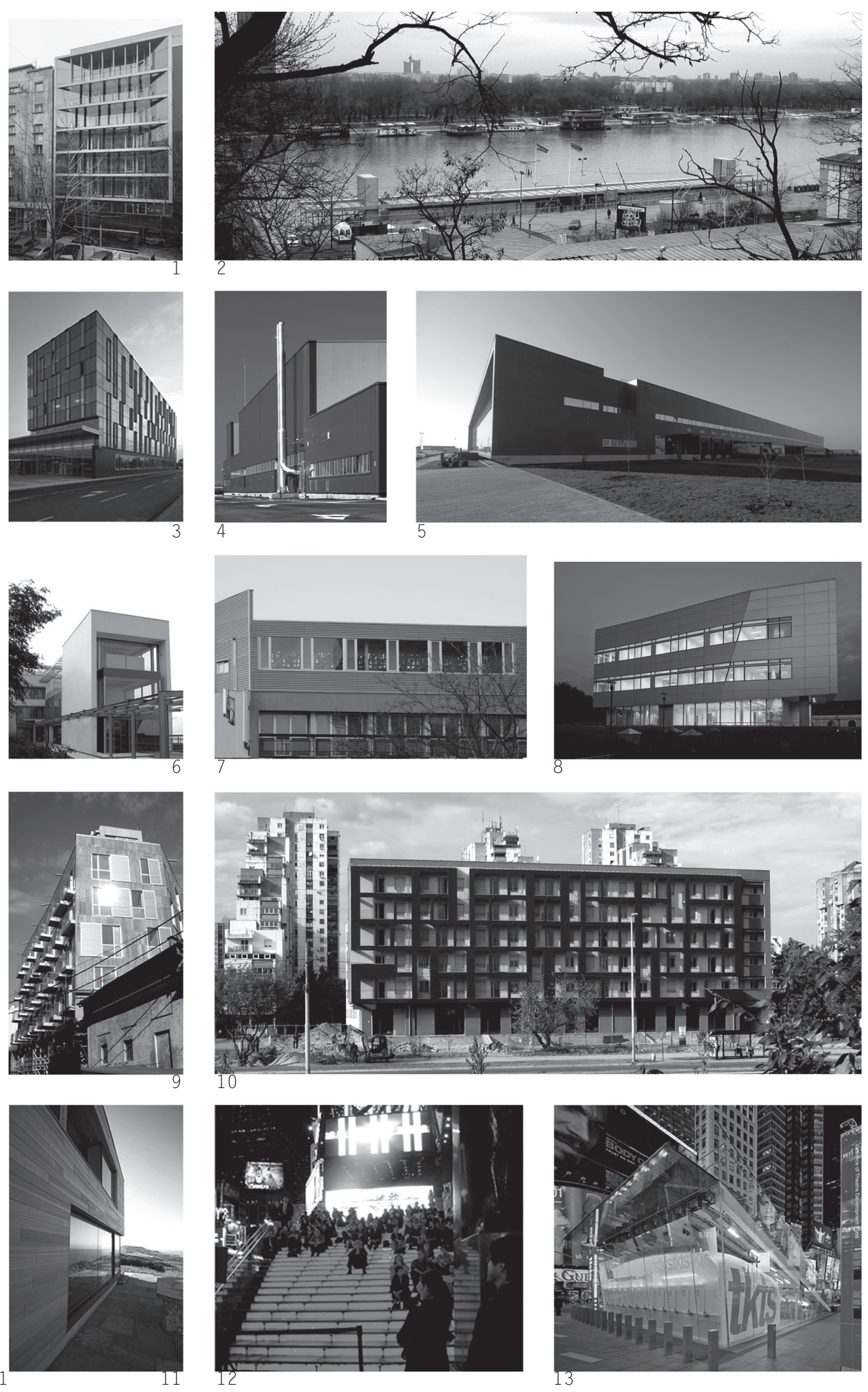
the multi-layered amalgamation of architecture with nature along with dynamics of association of people in the milieus of the gardens and parks, a masterfully grasped culture of atmospheres in which the light, the water and the air are liberated. Technological innovations of the modernized materials, the impregnated washi paper (membranes instead of glass and floors), the translucid marble cut thinly, the impregnated non-inflammable sugi wood, they all come as a result of an ethnical outlook and search for the special and the sole possible, with the new qualities of attributes of softness, transparency and the organic. Buildings are not built for their own sake, they are built of light and of water and with light sensors they make the invisible observatories concealed in a landscape. In the transcript of Kuma's lecture in the catalogue of the 29th Salon of Architecture it is stated: ...Architecture is a fascinating area ... Specific character of the location will become the norm in the architecture of the twenty-first century ... Products have characteristics, they are special and they can be realized only in one specific location... The effect of his visit and lecture transcended all other activities that year and may serve as a paradigm of existence and creativity in architecture and its subjects and also as a pattern for the coming age.

Besides Kengo Kuma, numerous guest architects, professors and theoreticians from the Netherlands, Austria, Germany, Switzerland, Spain and France held open public lectures, discussions or exhibitions at the Faculty of Architecture, the Week of Architecture in Belgrade and during the Architectural Salon, among them being Rem Koolhaas, Zvi Hecker, Hans Ibelings, Tom Main, Marc Armengaud, Neil Leach, Urlich Koenig, Idis Turato, Libeskind, Vedran Mimica, Vladimir Nikolić, Keller Easterling, Nikos Ktenas, leaving behind a vestige of their presence in the world to Belgrade's audience.

\begin{tabular}{ll}
\hline TABLE 1. \\
1 \\
2 & Office Building in Resavska Street, Belgrade, 2009. Goran Vojvodić and Aleksandar Hrnjez; \\
& International River Passenger Terminal, Belgrade Harbor, 2006. Dva: Studio: Aleksandru Vuja and Milan \\
& Djurić; \\
& Porsche Administrative Building, Belgrade, 2008. Goran Vojvodić, feat Grozdana Šišović and Dušan \\
& Radišić; \\
4 & Industrial Building, Indjija, 2008. Dva: Studio: Aleksandru Vuja, Milan Djurić and Sladjana Milivojević; \\
5 & Milšped Logistic Center, Stara Pazova 2007. Dva: Studio: Aleksandru Vuja and Milan Djurić; \\
6 & Residential Commercial Building, Dedinje, Belgrade, 2009. Medium International Development: Dejan \\
7 & Miljković and Jovan Mitrović; \\
8 & Faculty of Political Sciences, Belgrade, 2007.-, Mihailo Timotijević; \\
9 & Serbia's Laboratories Administrative Building, Batajnica, Belgrade, 2007. Agm Team: Marjan Djulinac, \\
10 & Borislav Petrović, Ivan Rašković, Aleksandar Tomić, Nada Jelić, feat Aleksandar Kostić; \\
& Residential Block in Sokolska street, Belgrade, 2006. Branimir Popović; \\
11 & Social Housing Apartment Buildings in New Belgrade, blok 61, 2009. Grozdana Šišović and Dejan \\
& Milanović; \\
$12-13$ & Extension of the Housing Apartment Building, Louicburgh, Ireland, 2007. Maša Bratuša and John \\
& Ruyane; \\
& Box Office and Red Glass Square, Times Square in New York, 2007. Nenad Stjepanović and colleagues.
\end{tabular}


The establishment of dialogue was stimulated by the visit to the Moscow Golden Section (2005) and by an exhibition and lectures by the renowned architect Boris Podrecca (2006). The new dialogue of Czech and Serbian architecture consisted of a series of lectures and exhibitions in the Museum of Applied Arts and the Faculty of Architecture: Yugoslav-Czech Architectural Links and the exhibitions $B I G D E A L$ by Igor Kovačević, Czech Cubism by Vladimir Šlapeta, and exhibitions by Oleg Haman and Aleš Podebrad (200607). Lectures were held in Prague in 2007 by Spasoje Krunić, Zoran Lazović, Aleksandar Videnović and Aleksandar Bobić.

The international character of the Belgrade International Architecture Week was created by a dialogue of Serbian and Austrian architects, the exhibitionspaper to list the numerous other activities. The institutions are made of people, not themselves... The activities of these events consisted of showing the exhibitions of the domestic architectural contests and world's architecture, the panels, the lecture and debates with participation of the domestic and a large number of world's architects, also accompanied by the events, workshops and theme walks, and it turned out that the week of architecture became a strong generator of changing architectural paradigm in Belgrade and in Serbia, which is yet to show its results. The merits for the benefits of this event can be at tributed to Jelena Ivanović - Vojvodić, Ružica Sarić and Ivan Kucina, not to mention the others.

The Salon of Architecture is the most important architectural event in Serbia, not only being the annual exhibition of Serbia's architectural achievements, but also as a documentary diary and emulsifier of quality which, every year since its foundation in 1974, has testified to the manner of ideas forming and use-related concepts implemented in diverse social circumstances and to the

Family House, mt. Povlen, 2006. Blagota Pešić;

Church Consecrated to the Birth of Holly Mother, Štipina, Knjaževac, 2006. Branislav Mitrović; New Monks' Lodge, Uvac, 1997. Blagota Pešić;

Mančić House, mt. Avala, 2001. Ivan Kucina and Nenad Katić;

Memorial Center, mt. Ravna Gora, 2001. Spasoje Krunić;

Residential Commercial Buildings, Užice, 2006. Mihajlo Timotijević and Miroslava Petrović Balubdžić; 

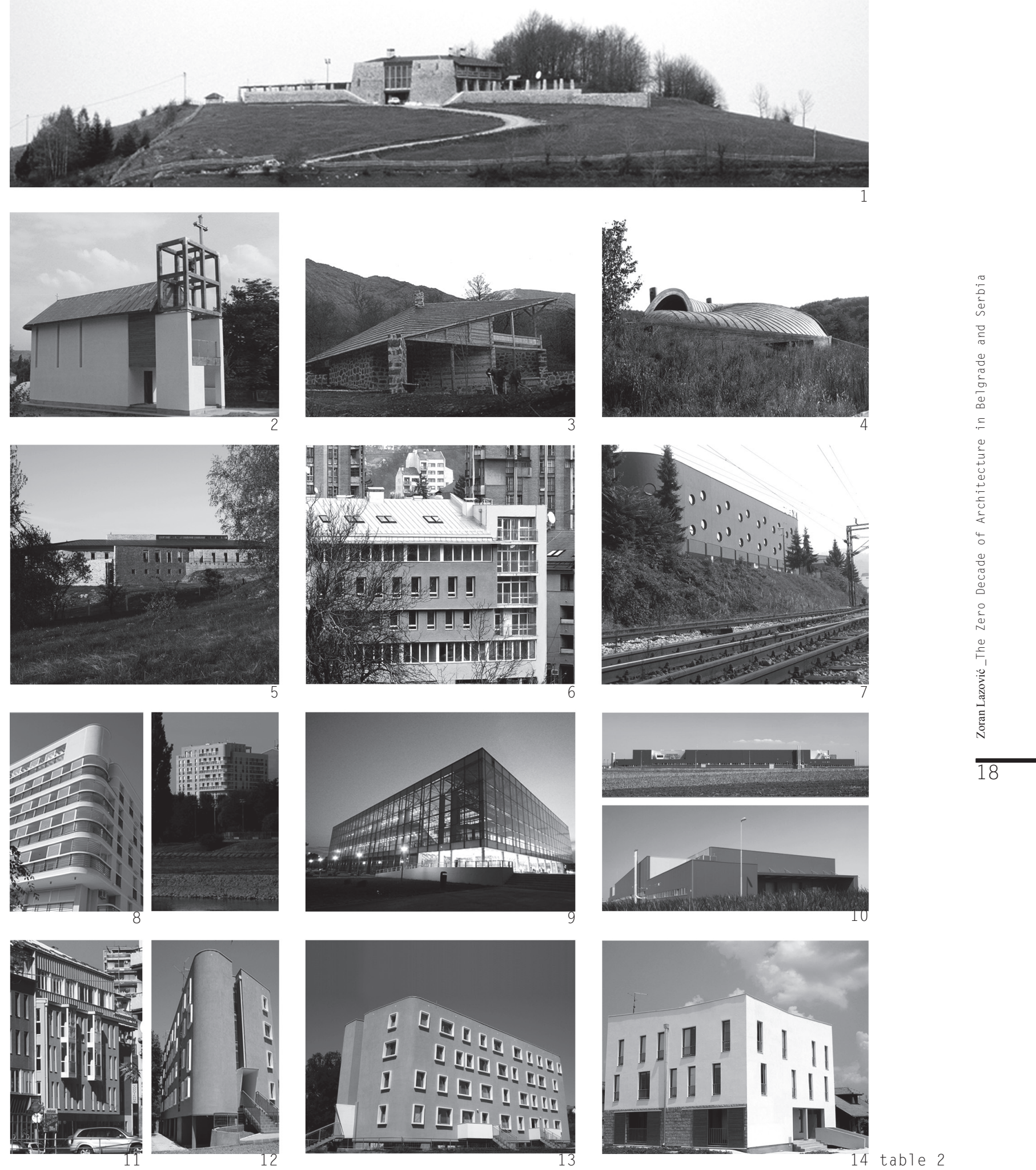
degree of culture attained. The propriety of the decisions made by the architectural companies, the members of the founder of the Salon community, and the commitment of many Salon commissioners has been demonstrated in the significance of the numerous records of the traces of architectural trends, especially during the social collapse experienced in the 1990s. The tradition of this congregational point of architecture now represents the cultural potential of the environment.

In the creation of a new culturological space through the contact and fusion of a number of related disciplines such as the art, the architecture, the design, the theory, the critique and the aesthetics, the participants,viz. Branko Pavić, Dragan Jelenković, Milorad Mladenović, Stevan Vuković, Miško Šuvaković, Ljiljana Blagojević, Vladimir Mako, Aleksandar Ignjatović and Ljiljana Miletić Abramović, are no longer alone in their activity. The new wave of the architectural critique of the reality today and which was established with the first issue (and the last one for now) of the new Forum edited by Milorad Mladenović, supported with the stability of the quality of DaNS, edited by Vladimir Mitrović. Decades of mystification, manipulation, concealment and subjective favoritism in architectural critique give way to a new, courageous, persistent, well-educated and objective generation. Co-operation of the Museum of Applied Arts, the Faculty of Architecture, The Association of the Architects of Belgrade, the Cultural Centre of Belgrade, Belgrade International Architecture Week, and numerous international architectural and cultural entities in diverse media expressions have produced a new, diverse and high-quality contents, the international dialogue and also the exchange of experience and ideas. Modernization of the educational approach at the Faculty of Architecture in Belgrade in conformity with the contemporary European standards and recommendations, orientated towards imagination, creativity and honesty of creation, has already achieved the internationally recognized results.

Not even the seclusion of Diaspora will any longer be unsupported by the younger in the relevant world results in the places that are more fertile groundsfor architecture. The extraordinary architectural results, along with Stojan Maksimović, Bratislav Gaković, Stanko Gaković, Bratislav Tošković, Ajla Selenić, Mirjana Milanović, Mikica Mitrašinović and many other architectural figures in Diaspora, have been achieved by Maša Bratuša in building and rescheduling of an existing house in Legan, Ireland, with a refined contextualism of the natural coalescing with the constructed, generating a magnificent image of harmony in forms of artifacts, the width of the ocean and 
the sky, the existence of the human aspect and the void of the place, the place of verdant character, of cedar and stone. Nenad Stjepanović with his colleague, winning the first award at a contest, has realized a box office and red glass square, a small urban stage, focusing the whole context at one point and creating Place with one minute but a very important building at the Times Square in New York.

\section{CONCLUSION}

Architecture, once again, has become the focal point, where in all the selfsufficient character of the trade and self-assessment after almost two decades of isolation from the rest of the world, we no longer can afford to be entitled to hold a monopoly on assessing our own values. Certainly, not assessing the omnipresent haute couture, but the authentic endeavors of architecture in a context. The competitiveness and competences of Serbian architecture are only possible if they engage in a constant comparative dialogue within the area of the European and global culturological fields.

It is clear that very few architectural projects are consequently implemented through architectural contests, not because there are too few or none of them, but because they are not respected as an institution, the authors have beenousted; the new ones inaugurated, or they have not made it as far as the execution. The rare examples are Pristan (pier) of the Belgrade passenger port and the social housing buildings of a modest size scattered across Serbia.

Designing the buildings as the state-funded investment was very rare and it has not attained the required architectural benchmark because there was no strong architectural competition or the quality and potential in the companies that won the tenders. The same thing happened to the reconstruction of schools, the children's institutions and public buildings. The cases of direct orders making sometimes, however, rarely, produced good results, not as regards the investors' enterprises for the market but more so when the clients placed the orders and built for themselves.

The symptoms of the situation or the problems of reality of the Island of Serbia are found in the hermetical character of a society which is not ready to face the new concepts and new technological and culturological patterns and also in the uncritical embracement of the new finished models. Dialogue and action are predominant in Belgrade and to some degree in Novi Sad but barely in Niš, if at all, but not in the all-but-forgotten remaining part of Serbia. The anticipated 
decentralization of municipalities has never taken effect. The responses lack the focus on what is important, conceptual, contextual and strategic. Creation of an entirely up-to-date cosmopolitan amalgam of architecture has been postponed. The foreign architects working in Serbia comprise no world-famous names, no international competitions have been organized for a long time, the public institution of architectural competition is also in jeopardy, and award-winning designs are very seldom realized in practice...

The responses to the problems inherited and created have been transferred to a neurotic boundary and situations this generation cannot solve - the traffic in all its forms, the cleanness / non-pollution of the air, the land and the waters, the concepts of public spaces and social architecture, orderliness of all environments, including green areas, the quality of life and level of expected contemporary (urban) culture. Instead of architecture, not just square meters, but acres of no name space, metastasizing of non-places, where money buys creative and professional criticality positions one by one and architecture gives way to the other professions, its own professional associations, bureaucratic mentality and plunder. De-professionalisation of society and the retreat of architecture from a sphere of influence to the bare needs and reality complete the Dirty reality transitional travesties and administrative submissiveness to power. Society's footprint in space, or space, product of society (Lefebvre)? It is not possible to exert influence upon the context and conditions of the existence of the profession...

The long-standing self-exile of proto-master Bogdan Bogdanović in Vienna reminds us that in the conflicting civic/communist society there is still a lingering monologue of ideologies, threats, non-democratic force of authorities, false nationalism and primitivism. The city of Vienna paid homage to one of the world's greatest figures in the area of memorial architecture, symbolic forms and literati, far above the local and the regional, and this was organized and held in the most elite place, in the Architecture Centre (2009).

The problems with memory cannot be avoided, the danger being that what has not been recorded has never even existed. The observance of architectural heritage and past values, which are the most important obligations of the contemporaries, lacks their systematic review, and has least of all been presented as such and promoted to the broader public as a common cultural value to be protected, also by legal regulations. Straying in architecture are also the consequence of insufficient awareness and acceptance of heritage, accompanied by complete ignorance of the society, the administrative services 
and the clients. Creation means: following heritage, accepting, adopting, creating what is new and better than the old and good (Goethe).

The professional criticality has never been cultivated or developed through the texts on architectural developments, public dialogue has long disappeared, no awareness has been raised among the professional and general public through dialogue and confrontation of opinions, and only rarely and unnoticeably did it exist in the form of designs, architectural competitions or completed projects. Architecture as a mission of culture is above all dedicated to life, as an investment, and not just for profit. Where are the Utopian projects of paradigm, where are the values of established attitudes, frankness, and stressing that only they can influence the reality? Do we remember Jovan Krunić, Milorad Pantović or Dejan Ećimović? Where has the heritage of the radical role of the architect in society vanished, and where are the principles of modern architecture for which Nikola Dobrović toiled and bled?

\section{THE LESSON FROM THE REGIONAL COMPARISON}

Opening up to the world and the departure from the self-referral of Croatian architecture, performed with systematic support from the state and professional associations for the young architects and their studios, the invitation to Stefano Boeri who had launched them into the world via the Zagreb Salon of Architecture, recognizing in their works the freshness and contemporary spirit of a new generation bearing a new quality of European references and standards. Hans Ibelings just continued from the same spot in 2009, but with much easier task than his predecessor had, because values had already been emulsified and standards set. The magazines ORIS and Dani ORISA helped create an international culturological level and abandon parochialism. An important role in this process was played by the continuity of the magazines Čovjek i Prostor and Arhitektura, but also premises accomplished through new norms of the architects' code of ethics and new European regulations and standards. Branimir Medić in the Diaspora, Amsterdam, and the Randić Turato tandem (agents of change in the architectural mission) is now stars of the European architecture.

Both of these milieus have developed new aesthetics realized on creative, rational and disciplined postulates through objective competition in a new market environment, openness and comprehension of the times. The new paradigms of European architecture once created in Holland are increasingly visible in the new Spanish architecture. The numerous competitions which 
helped rear a progressive new generation of young architects of a discrete culture of atmospheres creates a network of artifacts of architecture and articulated public spaces, also in decentralized areas. Modernity is realized by culture, culture is written with architecture, in well-developed systemic standards of living society and lively economic relations, through continuous rational and aesthetic choice, through dialogue and argumentation, competition with developed logistics in public presentation of processes and accomplished values.

\section{THE POTENTIALS OF ARCHITECTURE}

The act of architecture and construction is not just in terms of finance and investment, but much more in terms of idea and culture, communication, and there is an immanent necessity of the autochthonous and authentic architectural creativity in the fast times and expanded context in which architectural ideas and works are created, and stand opposed to the globality of the creation of generalities, repetition and imitation of architecture. The very intense and powerful flood of investments in which architecture barely survives, serves but not leads with its spirituality, skill and modernity and where context becomes negligible, is already recognized in the culturological national space and visibly makes a certain social damage. The paradox of high criteria along with limitation of the milieu's givenness. All in all, almost all the works, the authors and the participants in the changes mentioned in this paper have already been recognized and commended, testifying to awareness in the acceptance of changes and professional capacity to promote the new.

For the time being there is no succession of generations, in terms of access to competition for the youngest and young generations on equitable bases, the generations that perfectly and almost only directly understand the time and the moment of not only local „community” but at a much larger scale. They become ,technical slavery” of unreliable investments with suspicious quality and relations in akin bureaus, regardless of personal professional performances that are far above the given situations. Without optimism, creative euphoria, there are no creators in the realm of architecture, and resources of knowledge and skills, motives, freshness and joy of creation can easily get exhausted. Although it is said that every epoch is the same, this one seems to be, if not more difficult, then without the prospects of architecture.

The authors of the text „Belgrade the Capital“ finally come to completely demystify the Belgrade case study and the role of architects in its present 
and future life: „In the recent history of Belgrade, modern and post-modern theories and ideologies were almost wiped out by wideness and complexity of the urban reality phenomena. Traditional roles of architects and urbanists as visionaries, orchestrators and creators of urban structures were also wiped out under the influence of contemporary processes of urbanization where power is democratically interpreted from the market standpoint, and regulatory parameters are incomplete and changeable. As 'victims' of change of the role, architects and urbanists become disoriented, without the chance to participate actively in contemporary urban processes, unless as witnesses in describing events, constantly engaged in the 'research' of the search of the 'actual condition', far removed from the role of the transformer" ${ }^{\text {" }}{ }^{14}$

Once again, it is necessary to read carefully the competition designs in which numerous reflective paradigms and poetics partook but without being noticed (Neo-Architects). „Competition works warn us, among others the Slavija Square (2005) by Milorad Mladenović and the re//al group entitled: a Design from that position has become a veritable warning: society must articulate and express its programs of change, if it truly wants to change... It is in art that I see the space of that new strategy, because it is art that necessarily builds every new cultural model of society" .15 Andre Malraux said that art was a matter of measure, a measure that is so absent from relations/dialogue in all directions and among all social subjects, from politics to vocation, starting from conceptual level to the level of tactics, from town-planning visions and concepts to practice, all the way to the appearance of streets.

A shortage of architectural institutions and other architectural supports in the society testify to a profound lack of awareness of its existence in society and the state and that it should present itself through architecture. This means that hard work lies ahead in developing critical and institutional logistics. Let us once and for good turn our vision form the past towards the future...

A high-quality and educative architecture, of refined nerve, from which we learn and which makes us dignified (an example being decades-long continuity of original designs in Užice), rather than bitter, anarchic and alienated from the time, the place, the location and reality, is an immanent need and assistance to the identity of the milieu in the transitional decline. Looking towards the very essence of their profession, architects are also co-lateral thinkers (Keller Easterling), useful intellectuals (Mimica), who in spite of everything, armed with an idea, skill and patience, step by step build up a new milieu. Of course the pool of ideas of the 'invisible architecture' is far richer than that of completedworks in the architecture of grand personal endeavors at a small 
scale. The most important feature detected is the exceptional referenced quality of the personalities who are the champions of change, by their personal conviction, authenticity, paradoxically and by deviation from the patterns of the past, in a state of constant self-evaluation, constantly testing the layers of preceding strata. Volker Schloendorf, opening the FEST '08, The International Film Festival in Belgrade, said that "we cannot change the world, but we can influence the perceptions of others". The greatest potential of modern architecture, not only in Serbia, lies in generations of young architects, and let us recognize them publicly for the first time by giving them the space to work. Unfortunately, this year we will continue further without Miloš Bobić and Vladimir Milić, without those two, who, solely by their existence and their work, accomplished a great deal in the first steps of the new paradigms. 
Faculty of Architecture, University of Belgrade, Berlage Institute, Fakultät für Architektur der RWTH Aachen, 2006. pp. 204,

Vladimir A. Milić: Belgrade the Capital - Context, pp. 36,

Miloš R. Perović: Serbian 20th Century Architecture, Faculty of Architecture, University of Belgrade, Catalogue of the exhibition in the Cultural center of Serbia and Montenegro in Paris, 2006 ,

Vladimir Mako: Vision of the National within the Dynamics of the Contemrporary: Aesthetic Interpretation of Recent Serbian Architecture, in Serbia, The Venice Biennale 2006, 10th International Architecture Exhibition, The Serbian Pavillon: Serbia - New Efforts, Editor of the catalogue: Vladimir Mako, Museum of Applied Arts, Belgrade, 2006, without pagination,

Vedran Mimica, Petar Zaklanović, Ana Džokić i Milica Topalović: Belgrade the Capital, pp. 26,

Milorad Mladenović: E, in Serbia, The Venice Biennale 2006, 10th International Architecture Exhibition, The Serbian Pavillon: Serbia - New Efforts, Editor of the catalogue: Vladimir Mako, Museum of Applied Arts, Belgrade, 2006, without pagination, 